$1-1-1948$

\title{
Effect of certain protein levels on egg production and mortality in white leghorns
}

T. B. Clark

Follow this and additional works at: https://researchrepository.wvu.edu/ wv_agricultural_and_forestry_experiment_station_bulletins

\section{Digital Commons Citation}

Clark, T. B., "Effect of certain protein levels on egg production and mortality in white leghorns" (1948). West Virginia Agricultural and Forestry Experiment Station Bulletins. 331.

https://researchrepository.wvu.edu/wv_agricultural_and_forestry_experiment_station_bulletins/334 
Digitized by the Internet Archive in 2010 with funding from

Lyrasis Members and Sloan Foundation 


\section{Effect of Certain Protein Levels on Egg}

\section{Production and Mortality}

\section{in}

\section{White Leghorns}

T. B. Clark, T. D. Runnels, J. H. Rietz, and C. E. Weakley, Jr.

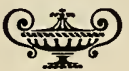

AGRICULTURAL EXPERIMENT STATION

COLLEGE OF AGRICULTURE, FORESTRY, AND HOME ECONOMICS WEST VIRGINIA UNIVERSITY

C. R. ORTON, Director MORGANTOWN 



\title{
EFFECT OF CERTAIN PROTEIN LEVELS ON EGG PRODUCTION AND MORTALITY IN WHITE LEGHORNS
}

\author{
By T. B. CLARK, ${ }^{1}$ T. D. RUNNELS, ${ }^{2}$ J. H. RIETZ, ${ }^{3}$ and \\ C. E. WEAKLEY, JR. ${ }^{4}$
}

The PROTEIN REQUiREments for growth in chickens have been studied extensively. From these studies optimum levels of protein have been determined for the starting and growing periods. Relatively less attention has been given to the effect of the level of protein in the starting and growing rations on the subsequent performance of the pullets. It is generally agreed that a high level of protein is required for body formation during the first few weeks of growth; as the pullets approach maturity their requirement for protein becomes less. It does not seem, however, to be so well recognized that, although their requirement for growth is met largely by the time laying starts, laying birds must have sufficient protein to meet the heavy demands of egg production as well as for the formation and maintenance of the vital body structures.

The probable interrelationships of protein level, rate of growth, egg production, and mortality afford matter of speculation to poultrymen. Many maintain the view that high levels of protein feeding during the growing period force growth too rapidly and that the pullets so fed are unable to withstand the strain of intensive egg production. Others hold to the belief that feeding a high level of protein during the laying period contributes to an increase in the percentage of organic trouble. Literature on the first question is conflicting, while there appears to be little information on the second question. It would appear from practical observations that the optimum protein level for intensive egg production is higher than that commonly recommended and that the level fed in the growing period might be related to the subsequent performance of the pullets.

An extensive review of the literature dealing with protein in poultry nutrition has been made recently by Hill (10). The following is only a partial review dealing with the level of protein in the growing or in the laying period, and with the effect of these levels on the performance of the pullets in the latter period.

In earlier work at this Station, Atwood (1) found that unsatis-

1 Associate Poultry Husbandman.

2Former Research Assistant in Poultry Husbandry, now with Cooperative Mills, Inc., Baltimore, Md.

3 Animal Pathologist Emeritus.

4 Associate Chemisi. 
factory egg production resulted when a ration consisting mainly of grain and wheat byproducts was fed during the starting and growing period unless supplemented with an unlimited quantity of skimmilk.

Morris et al. (15) fed rations varying in protein content from 14 to 24 percent from day-old to sexual maturity. After 16 weeks of age the growth was practically the same in all lots. The average age at first egg and the average first-year egg production for the 6 lots on the same laying ration was practically the same.

Winter et al. (19) concluded that it is desirable to change from a. starting to a laying ration at 8 to 12 weeks of age allowing free choice of grains without use of a low-protein growing ration. This system resulted in larger and more uniformly developed pullets that laid more intensively. No relationship was noted between protein level of the mash and age at first egg. Whether the results were due to the higher protein level or to the higher vitamin content of the laying mash was not determined.

Byerley et al. (3) found a low but significant positive correlation jetween percentage of protein in the ration and percentage of production after first egg when the protein increased from 11.2 to 23.6 percent. Increasing the protein level within these limits increased the quantity of egg produced per unit weight of feed consumed; but it decreased the efficiency of protein for egg production. 'The hens survived equally well on each of the rations.

Heiman et al. (11) fed six rations ranging from 12-13 to 18 percent of protein, using triplicate lots of pullets. With the all-mash rations used, 14 percent of protein was the minimum requirement for an average production rate of 60 percent. There was no increase in egg production above the 14 percent level. No relationship was found between level of protein fed and the mortality of the pullets because of the wide variation in mortality within ration groups.

Heuser and Norris (12) concluded that a wide range in protein may be fed and still result in satisfactory growth. High protein levels are not harmful and are to be preferred to low-protein rations which retard growth. These workers were unable to draw definite conclusions regarding the relationship of protein level to mortality. Sexual maturity was not influenced markedly by the protein content of tie ration, an otservaion made by Winter et al. (19), Dearstyne et al. (7), Byerley et al. (3), Morris et al. (15), and others. These workers agreed in general that a high level of protein apparently does not hasten sexual maturity, but a level of protein low enough to retard growth will delay sexual maturity.

St. John et al. (17) observed that the percentage of protein in the ration before the 10th week or after this period did not influence egg production after the 24th week and that the amount of protein in the ration after the 10 th week did not influence the rroduction before the 24 th week. The protein in the ration before 
the 10 th week did influence the maturity; the pullets on 17 percent protein started to lay 1 week earlier and those on the 21 percent ration started to lay 2 weeks earlier than those on the 13 percent ration. A similar observation has been made by Carver et al. (4) and by Carver et al. (6).

Heuser (13) found that a 14 percent protein ration gave satisfactory egg production, but unlike the 16 percent ration it did not maintain body weight or egg size. A 12 percent ration was completely unsatisfactory.

Bronkhorst (2) concluded that differences in protein level of the laying mash had no effect on egg production. Prolapse of the oviduct and pick-outs occurred more frequently in the two lower protein groups.

Tomhave (18) found that within the limits used-14 to 18 percent-the protein level fed during the growing period did not greatly influence the number of eggs produced during the first laying year. Mortality was increased during the first year of production whenever the protein level of the growing ration was below 18 percent during the first 8 weeks. Growing the pullets on range did not reduce mortality below that obtained with confinement rearing.

Gutteridge et al. fed 3 levels of protein during the growing period. With pasture available, they fed a 15.5-percent protein mash to 7 weeks of age and followed with a regular reduction in protein, so that a 13.7-percent protein level was reached at 24 weaks. From this they obtained as good results as from starting with 20 percent and reducing to 14.75 percent. Using the same groups reared on the low, medium, and high protein levels, Gutteridge et al. (9) concluded that the medium level $(14.5 \%)$ during both the rearing and laying periods gave as good results as those obtained from the 16.5-percent level. They found that the 12.5-percent level was too low for either satisfactory growth or egg production. In the laying period the mortality associated with the high protein level was significantly greater than that of the other groups. In the growing period the mortality was lowest on the high-protein ration.

Platt and Stover (16) found that the use of low-protein rations before the birds were 12 weeks of age retarded growth, increased chick mortality, and delayed sexual maturity. They found no effect from protein level in the growing period on body weight, egg production, or mortality of mature birds. They concluded that the retarding of growth and maturity with low-protein growing rations does not appear to be economically sound for pullets hatched in March and April.

The studies reported herein deal with the use of two different leve's of protein feeding curing the growth period and with four levals ciuring the laying period, using both pullets and hens. The 
effects of these levels on egg production and mortality were the pertinent considerations, but additional data on body and egg weight arid on feed efficiency are also included. Lack of facilities made it impossible to determine the optimum level of protein. Arbitrary limits in protein levels were set up, not too extreme, for studying the performance of the birds under the conditions of this experiment. These studies involved the same populations during both growing and laying periods.

The chief criticism of work of this kind is that the groups seldom are replicated sufficiently for satisfactory conclusions, especially in regard to mortality. It conceivably may be influenced by many environmental conditions. The assumption that minor changes in the diet can be measured with small numbers of birds likely would result in erroneous conclusions. In these trials the lack of facilities prevented the use of replicate lots within years, but it was believed that the weight of numbers over a period of five or more years would provide acceptable data.

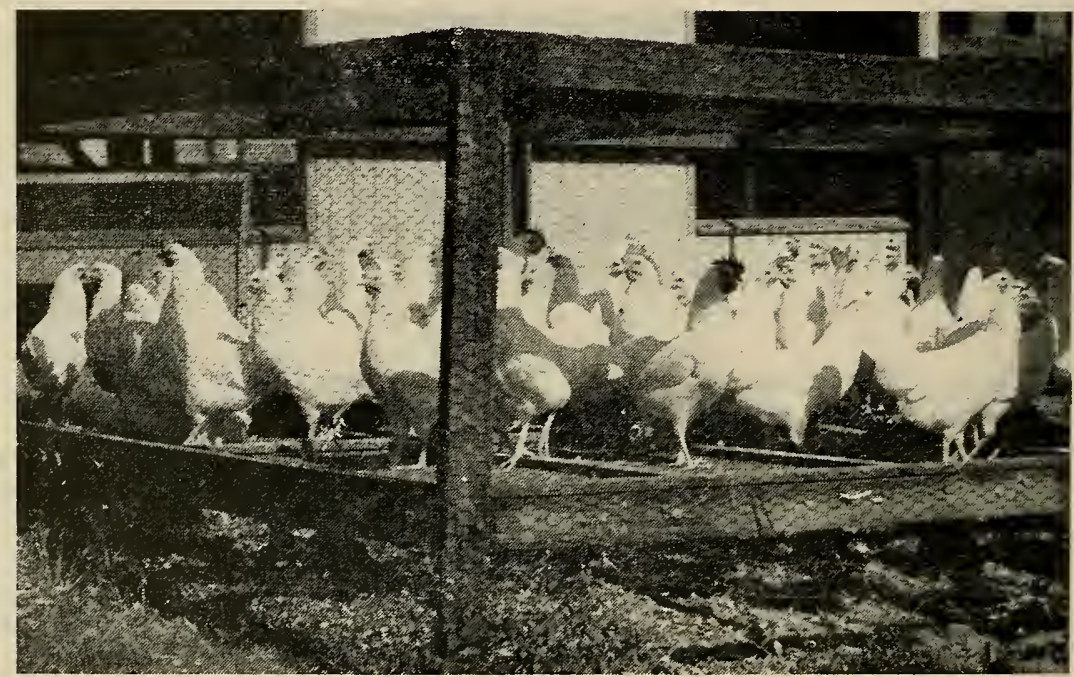

A High-protein Lot Reared in Confinement

\section{PLAN OF EXPERIMENT}

White Leghorns from the Agricultural Experiment Station flock in which selective breeding was being conducted were used throughout this experiment. The pullets used in the first year varied in age when they were housed, but in the following years all pullets within lots were of the same age. The pullets in the first as well as in the following years were distributed between the ration groups according to dam and body weight. The males used were from those 
selected for breeding purposes in the Station breeding flock. In the first three years, males from more than one dam were used in the Lot A pens. After this period, males from one dam were used in each pen. In all years the males were rotated at intervals between the pens before and during the hatching season.

Chicks were hatched from the Lot A pens each year. They were brooded in 10' $\times 12^{\prime}$ brooder houses heated with electric brooders. The cockerels were removed at 4 or 8 weeks of age. Except where noted, the pullets were reared in confinement in the brooder houses with access to $10^{\prime} \times 16^{\prime}$ sunporches.

The chicks were pedigree-hatched and the progeny of each dam were wing-banded and distributed between the two protein-ration groups. The A-lot chicks were always 2 weeks older than the B-lot chicks. During the first 3 years the distribution was made at day-old but later this was done at 4 weeks of age. In the first year the chicks were started on the high- and low-protein rations at day-old, but each year thereafter they were started on the high-protein ration and divided into two lots at 4 weeks of age, one-half of each lot being fed the high-protein and the other half the low-protein ration. The birds were weighed at day-old and every 4 weeks thereafter for the duration of the experiment. Feed consumption records likewise were obtained at 4-week intervals during both the rearing and laying periods.

The all-mash rations used are illustrated in Table 1. Except for short periods these formulas were adhered to strictly. During the last laying year, 1942-43, the protein concentrates were changed because of the feed shortages, soybean oil meal being substituted for the menhaden fish meal. The rations were mechanically mixed every two weeks under rigid chemical control to maintain the percentage of protein at the desired levels. Except for bone meal, all protein-carrying feed ingredients were individually mixed in 500lb. lots, then sampled and analyzed. After mixing, each ration itself was sampled and analyzed. The average protein analysis and standard error for each year are given in Table 1. During the first two years the basic rations, hereafter referred to as high- and low-protein, were mixed to contain 18 percent and 14 percent protein, respectively. The following year this difference was widened to 18.5 percent and 13.5 percent. The percentage of calcium and of phosphorus was determined occasionally to maintain the level at 1.8 and 0.9 percent, respectively. All-mash rations were used during both rearing and laying periods, no change being made in the formulas when sexual maturity was reached. These rations were kept before the birds continuously. During the laying period, oyster shell and grit were provided.

The pullets were leg-banded and moved to the laying pens at 20 to 24 weeks of age, then placed on the planned protein level of feeding. All birds within lots were of the same age when this 
change was made. At this time unhealthy pullets were culled; extremely large or small pullets also were culled if more pullets were available than could be housed. No culling was done after the pullets were placed in the laying pens. Individual egg records were kept. The eggs were weighed on a gram scale in the last 7 days in each 28-day period. Lights were used to provide a 13-hour day during the laying period.

All layers that died and those in a moribund condition were autopsied to determine, if possible, the cause of death and whether this was related to the percentage of protein in the ration. The findings were recorded and have been grouped under three main headings: leukosis complex, reproductive disorders, and miscellaneous. Some birds appear in more than one classification; thus the percentages for classes may be greater than the total percentages. All birds showing a lymphoid deposit in any organ of the body were classified under leukosis complex. In many cases the determination was made by microscopic examination of stained sections from the suspected organs. Birds showing egg concretions, yolk in

TAELE 1-Fypal Formulas of All-mash Rations used with Average Protein Analysis and with Standard Error for Each Year

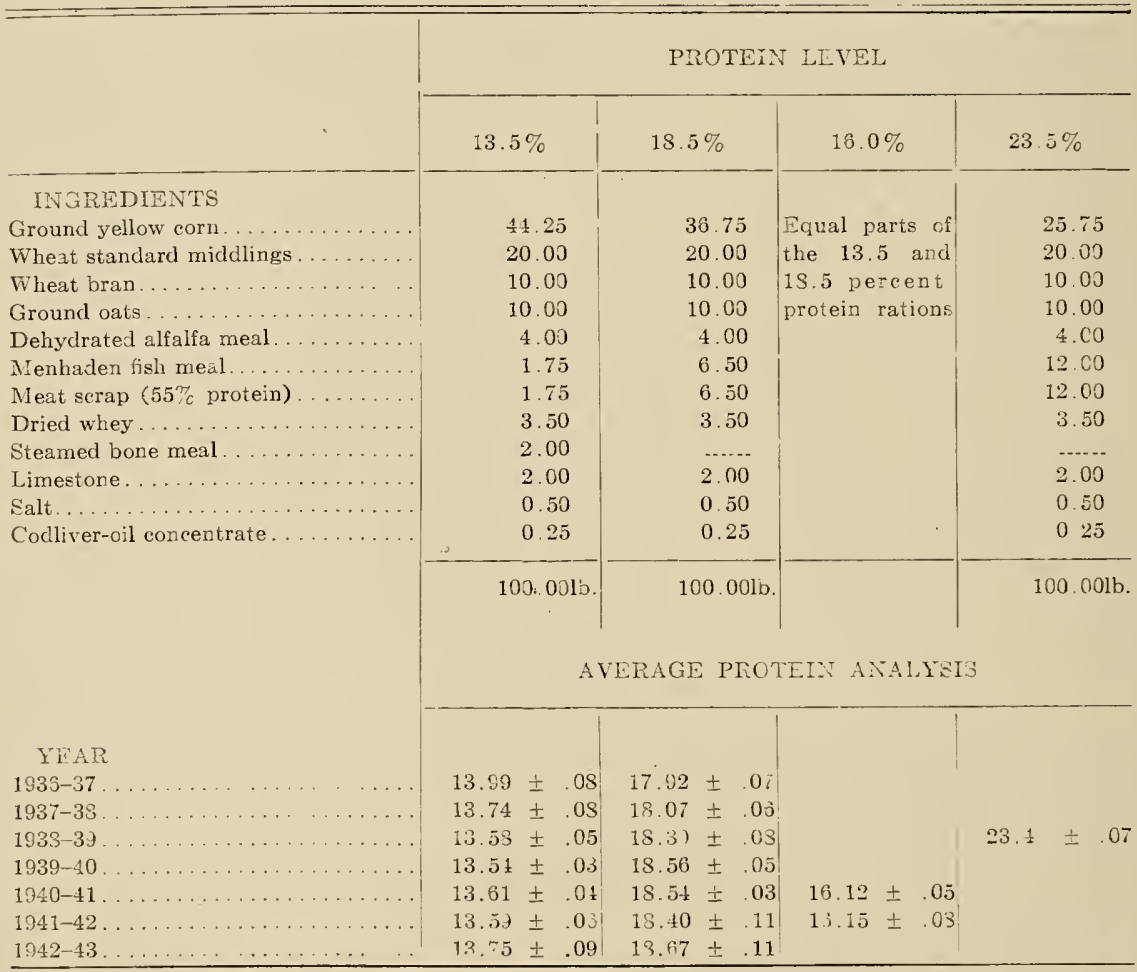


the peritoneal cavity, and/or large, irregular, flabby hemorrhagic ovaries were classified under reproductive disorders. Under "misscellaneous" are grouped all conditions other than leukosis complex and reproductive disorders, $i$. e., enteritis, heat prostration, mechanical injuries, cannibalism, pox, parasites, roup, and no diagnosis,

The laying year usually was 124 -week periods, but some lots were continued for 13 periods. The values for percentage of egg production were computed on a bird-day basis in which all floor eggs were included. The days between the time a bird died and its last egg were omitted in computing the bird-days.

\section{EXPERIMENTAL RESUlts}

\section{EXPERIMENT 1}

The A lots in this experiment were housed on October 19, 1936. These two lots of pullets were selscted from the Station flock which had been grown on range and fed a growing ration of mash and grain ad lib. The average protein consumption probably was between 15 and 16 percent. These pullets varied in age. Some were in egg production while others were just starting to lay when housed. Listribution was made, as far as possible, according to dam, body veight and age. The A lots were maintained on this experiment for 2 years to determine the effect of the protein levels beyond the first laying year. The B lots were hatched on April 30, 1937, from eggs produced by the A lots. These lots were started on the respective rations when the chickens were one day old.

The results secured from the $A$ lots for the 2 years and for the $B$ lots for one year are reported in Table 2. The respective laying rations for each lot of pullets and the number of birds at the start of each laying year are indicated.

Even though the average body weights of the A lots at the start of the first laying year did not differ significantly, their yearly averages differed significantly in both the first and second years in favor of the high protein ration. On the other hand, the B lots which did differ significantly at the start had similar yearly averages.

The different levels of protein had no significant influence on the yearly average egg weight. No difference was expected in the egg weight during the first period for the A lots, since the birds were distributed uniformiy. In the $B$ is, where no distribution was made, the pullets being kept on the same level of protein, there is no difference in egg weight for the first period, even though the body weight at the start differed significantiy.

The total percentage of mortality for the A lots in each of the 2 years is practically equal. It is higher the second year, but there is no definite trend for either protein level. The total mortality for the low-protein B lot is 7.8 percent higher than that of the other 
group, a large part of which occurs in the miscellaneous group, but this difference is not significant. The percentage of reproductive disturbances is lower in all groups fed the low-protein ration as compared with those on the high-protein ration. There is no apparent relationship in the other classifications to level of protein.

The difference of 5.3 in the percentage of egg production of the A lots during the first year is highly significant, but the egg production for these lots is practically the same the second year. The production of the survivors on the low-protein ration was lower the first year than that of the other A lot, but the difference is not significant. The production of the survivors for the second year is nearly the same, but the position is reversed. In the B lots, the protein level had a definite influence on egg production as shown by significantly higher values in the high-protein group for both percentage of egg production and production of the survivors.

TABLE 2-Summary of Results for Experiment 1

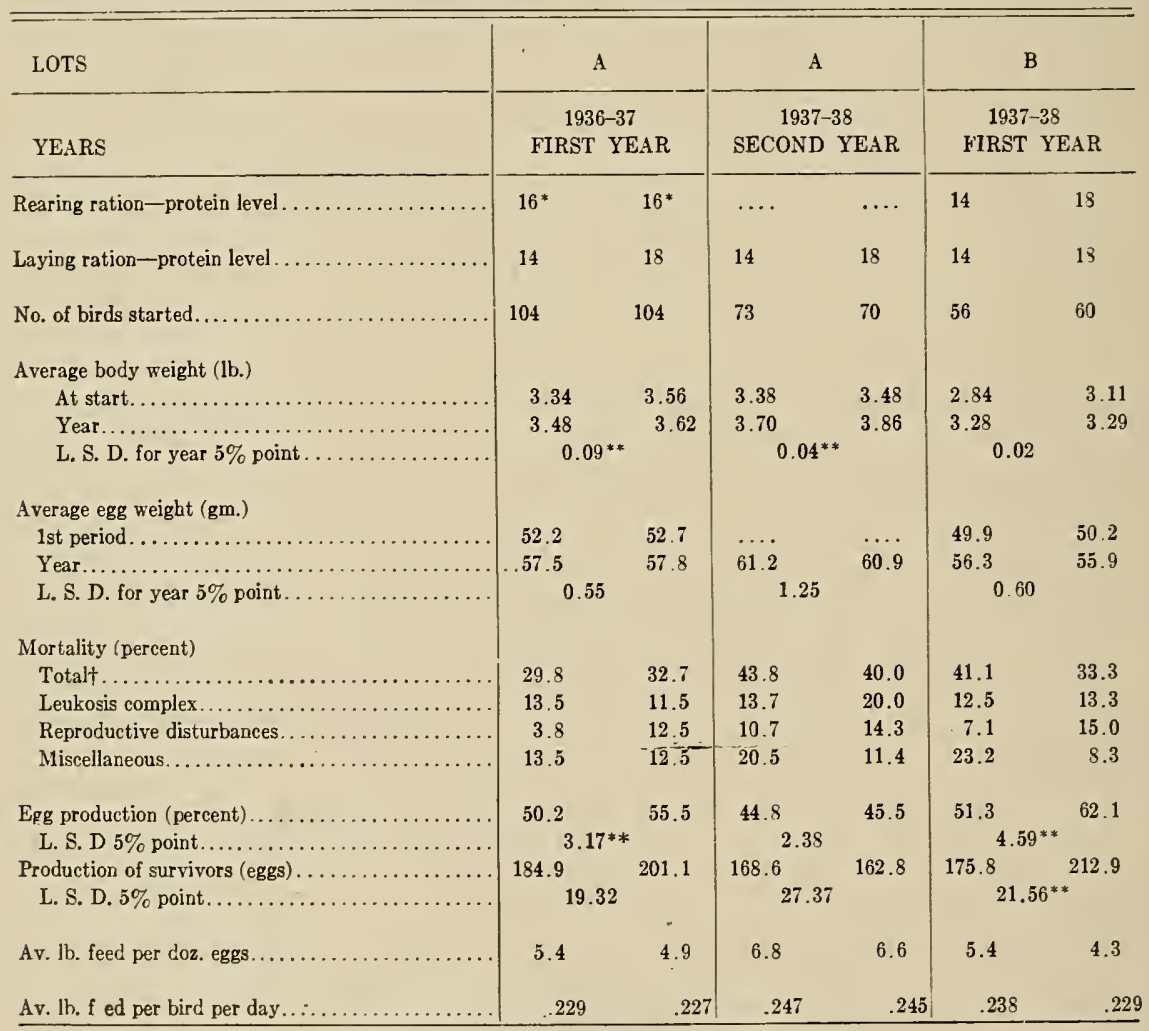

* Reared on grass range after 8 weeks of age and fed mash and grain ad lib.

The protein level is estimated.

$\nmid$ Discrepancies caused by duplications (Table 9 ).

**Difference exceeds 1-percent level of significance. 
The trend of the egg production values of the A lots in the first year is in the same direction, even though the difference between rations for the survivors might be due to chance. In the second year the differences between rations for either value are not significant, suggesting that a 14 percent level of protein is high enough for egg production in the second year. The birds have obtained their body growth, and probably less protein is required than in the first year. In this experiment it is evident that rearing the birds on the normal level of protein, and then changing to a lower protcin level, did not have the marked effect on either mortality or egg production like that which resulted in the B lots, where the birds were kept on the low protein level throughout both rearing and laying periods.

\section{EXPERIMENT 2}

This experiment was designed to study the effect of reversing the rations fed to one-half the pullets at 20 to 24 weeks of age and comparing them with those kept on the same rations fed in the growing period and to maintain the pullets on the different rations for 2 or more laying years. The chicks were hatched April 26,1938 , from the 1937-38 A lots. They were distributed uniformly from each pen into two groups and started on the high-protein ration. At 4 weeks of age one group was changed to the low-protein ration. At 22 weeks the pullets in each group were again divided according to pedigree and body weight, so that one-half of the pullets on the low-protein ration were left on the same ration while the other half were changed to the high-protein ration. The same division was made for the pullets on the high-protein ration. Each 2 groups were placed together in the same laying pen, so that each laying group consisted of birds from each of the 2 rearing groups in approximately equal numbers. These groups were thus maintained for 39 4-week pericds. A summary of results is given in Table 3.

The average body weight at the start of each year is slightly higher for the groups reared on the high-protein ration. The average yearly body weights for the different lots within years differ significantly. The general trend is for the high-protein ration to maintain body weight better than the low-protein ration during all three years.

The average egg weights of these groups for the first period and for the first year do not differ significantly. In each of the following years, however, the yearly average egg weight of the low/low group is significantly lower than that of the other groups.

'The total percentage of mortality for the low/high group is the lowest the first year, but it is the highest the third year. The mortality over the three vears for all groups shows no consistent trend except that those groups having a low mortality in the beginning had a higher rate the following years. At the end of the third year 


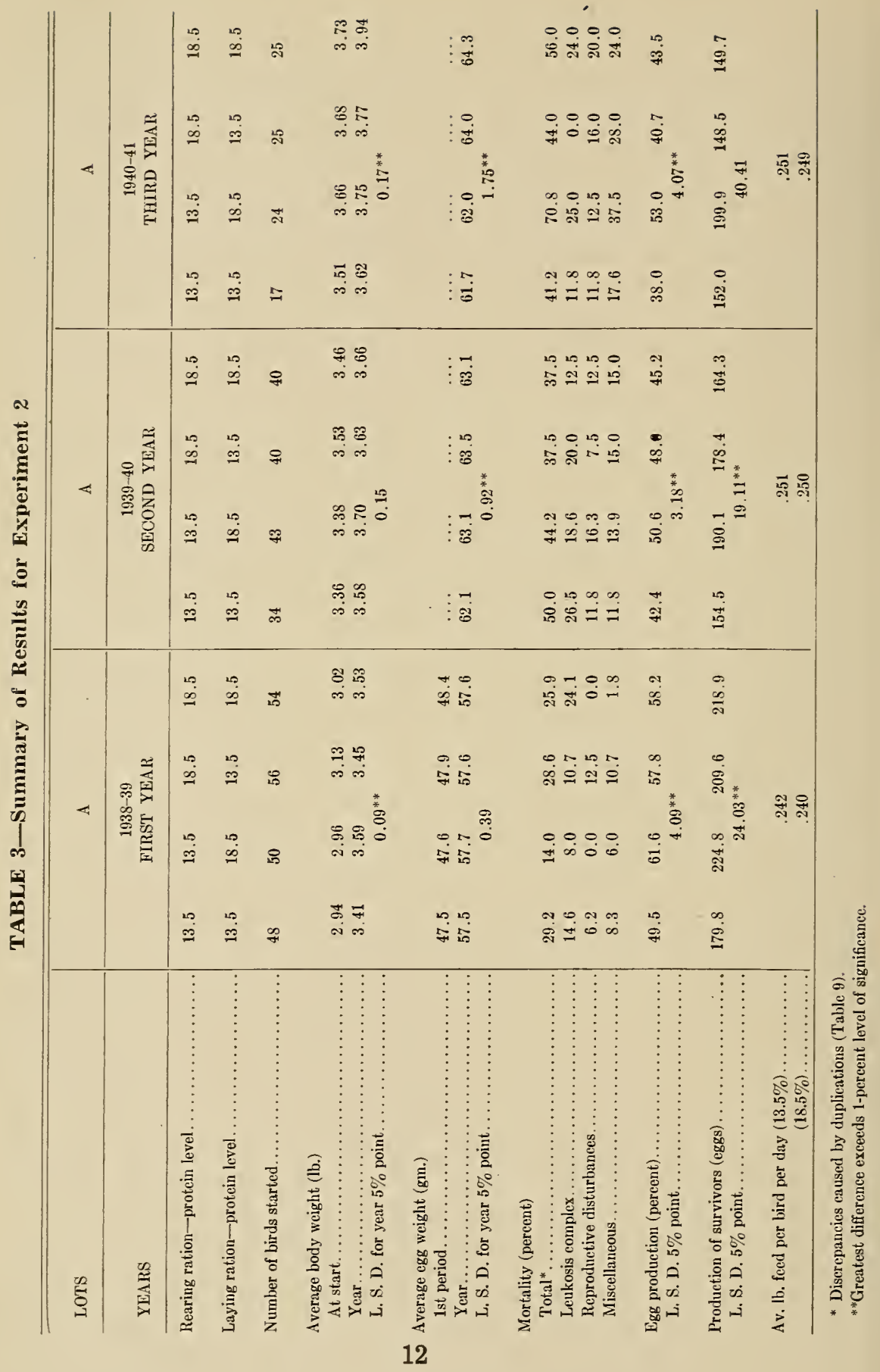


there were $10,7,14$, and 11 birds alive for the groups in the order given in Table 3 . The total percentage of mortality for each group for the three-year period was 79.2, 86.0, 75.0, and 79.6, respectively. Thus the different protein levels had little influence on mortality when the three years are considered as a single period. There is no definite trend in regard to the different disease classifications except that the leukosis complex accounted for the greatest mortality in most of the groups during the first two years.

The percentage of egg production for the low/low group is lowest in all the years, while the low/high group had the highest percentage of production and the highest production for the survivors. The survivors of this group show a significantly higher production in all years than do the other groups. When the percentage of egg production for the 3 years was analyzed by the analysis of variance, the high-protein laying ration gave significantly higher egg production. On the average, egg production was not affected by the rearing ration.

\section{EXPERIMENT 3}

The results for the three B lots in this experiment are summarized in Table 4. These lots were hatched from eggs produced by the birds on Experiment 2 and subjected to the indicated feeding regimen.

The first group (1938-39), hatched May 3, 1938, were allowed free range on a bluegrass pasture after 8 weeks of age and were fed the same rations during both rearing and laying periods. They were housed at 22 weeks of age. They are comparable with the A lots (1938-39) reared in confinement, except that the latter were hatched a week earlier and housed at 24 weeks of age.

The average initial body weights for the lots are practically the same, but the average body weights for the year differ significantly.

The egg weight is smaller for the low/low protein group the first period, but the position is reversed for the yearly average. The significantly higher yearly egg weight for the low/low protein group may have resulted from the higher mortality in this group, the smaller egg hens having died early in the year.

The total mortality is significantly higher for the low/low protein group, being 45.1 percent as compared with 11.5 percent for the other group. Of the 23 birds that died in the first group, 13 were cannibalized. Since these birds had been reared on open range, it is possible that the change to confinement, together with the low-protein ration, brought about the outbreak of cannibalism. The effect of low-protein rations on cannibalism will be discussed later.

In this as in the previous experiment the percentage of egg production and the production of the survivors are significantly higher for the high-protein group. 
The 1939-40 B lot were hatched April 24, 1939. The 18.5 percent protein thus far had not seemed to produce a detrimental influence. A third group was included and fed a ration containing 23.5 percent protein. This group was made up of pullets from both low- and high-protein rearing groups.

The results from these trials are comparable in nearly all respects. This is the first trial in which the egg production of the low/low protein groups is not significantly lower than that for the higher protein level. It is of interest to note that the highest-proteinration group $(23.5 \%)$ did not have a higher mortality or higher percentage of egg production than did the other groups.

TABLE 4-Summary of Results for Experiment 3

\begin{tabular}{|c|c|c|c|c|c|c|c|c|}
\hline LOTS & \multicolumn{2}{|l|}{ B } & \multicolumn{3}{|c|}{ B } & \multicolumn{3}{|c|}{ B } \\
\hline YEARS & \multicolumn{2}{|c|}{$\begin{array}{l}\text { 1938-39 } \\
\text { FIRST YEAR }\end{array}$} & \multicolumn{3}{|c|}{$\begin{array}{l}1939-40 \\
\text { FIRST YEAR }\end{array}$} & \multicolumn{3}{|c|}{$\begin{array}{c}1940-41 \\
\text { FIRST YEAR }\end{array}$} \\
\hline Rearing ration-protein level. . & $13.5^{*}$ & $18.5^{*}$ & 13.5 & 18.5 & $\begin{array}{r}13.5 \\
\text { and } \\
18.5\end{array}$ & 13.5 & 18.5 & $\begin{array}{l}13.5 \\
\text { and } \\
18.5\end{array}$ \\
\hline Laying ration-protein level... & 13.5 & 18.5 & 13.5 & 18.5 & 23.5 & 18.5 & 13.5 & 16.0 \\
\hline Number of birds started... & 51 & 52 & 54 & 47 & 54 & 49 & 50 & 43 \\
\hline \multicolumn{9}{|l|}{ Average body weight (lb.) } \\
\hline At start............. & 3.19 & 3.19 & 3.00 & 3.00 & 2.94 & 3.35 & 3.43 & 3.25 \\
\hline Year................. & 3.44 & 3.60 & 3.53 & 3.53 & 3.48 & 3.71 & 3.57 & 3.62 \\
\hline L. S. D. for year $5 \%$ point. . & \multicolumn{2}{|l|}{$0.09^{* *}$} & \multicolumn{3}{|c|}{0.07} & \multicolumn{3}{|c|}{0.14} \\
\hline \multicolumn{9}{|l|}{ Average egg weight (gm.) } \\
\hline 1st period $\ldots \ldots \ldots \ldots$ & 48.4 & 50.1 & 48.7 & 49.3 & 49.6 & 52.2 & 59.3 & 51.2 \\
\hline Year.................. & 58.5 & 57.4 & 56.3 & 56.6 & 56.4 & 60.6 & 59.3 & 58.9 \\
\hline L. S. D. for year $5 \%$ point.. & \multicolumn{2}{|c|}{$0.70^{* *}$} & \multicolumn{3}{|c|}{0.67} & \multicolumn{3}{|c|}{$0.50 * *$} \\
\hline \multicolumn{9}{|l|}{ Mortality (percent) } \\
\hline Totalf........... & 45.1 & 11.5 & 27.8 & 23.4 & 22.2 & 42.8 & 28.0 & 44.2 \\
\hline Leukosis complex.......... & 11.8 & 3.8 & 7.4 & 8.5 & 7.4 & 16.3 & 6.0 & 4.6 \\
\hline Reproductive disturbances... & 21.6 & 3.8 & 13.0 & 6.4 & 5.5 & 10.2 & 2.0 & 2.3 \\
\hline Miscellaneous............. & 19.6 & 3.8 & 9.2 & 10.6 & 13.0 & 20.4 & 20.0 & 37.2 \\
\hline $\begin{array}{l}\text { Egg production (percent) } \ldots \ldots \\
\text { L. S. D. } 5 \% \text { point. . . . . . }\end{array}$ & \multicolumn{2}{|c|}{$\begin{array}{c}57.45^{66.0} \\
2.85^{* *}\end{array}$} & \multicolumn{3}{|c|}{5.23} & \multicolumn{3}{|c|}{$4.11^{* *}$} \\
\hline $\begin{array}{l}\text { Prodnction of survivors (eggs). } \\
\text { L. S. D. } 5 \% \text { point. ......... }\end{array}$ & $\begin{array}{l}193.0 \\
24.1\end{array}$ & 225.0 & 180.5 & $\begin{array}{c}183.3 \\
10.16\end{array}$ & 184.1 & 198.3 & $\begin{array}{l}183.0 \\
19.8 S^{* *}\end{array}$ & 212.7 \\
\hline Av. lb. feed per doz. eggs....... & 5.1 & 4.3 & 5.7 & 5.3 & $\ldots$. & 5.1 & 5.3 & ... \\
\hline Av. lb. feed per bird per day... & .245 & .241 & .253 & .245 & .245 & .244 & .247 & .243 \\
\hline
\end{tabular}

* Reared on grass range after 8 weeks of age.

† Discrepancies caused by duplications (Table 9 ).

** Greatest difference exceeds 1-percent level of significance.

The 1940-41 B lots were hatched April 19, 1940, to provide further information on reversing the rations during the laying period. 
It had been observed in Experiment 2 that the pullets, when reared on the low-protein ration and then changed to the high protein for the laying period, produced more eggs than did those in the other ration groups. In addition, the mortality was lower the first year. Since the 23.5 percent protein ration produced results no better or worse than the other levels, it was decided to use an intermediate level, 16 percent, for comparison. This group was made up from both rearing groups.

The yearly average body weight and the yearly average egg weight for the low/high protein group are significantly greater than the same values for the other two groups.

The total mortality for the first two groups is reversed as compared with that of the 1938-39 A lots in Experiment 2. In the latter experiment the low/high protein group had a lower mortality than the high/low group during the first laying year.

Here again the trend is for the low/high group to lay more eggs than the high/low group, but, as in Experiment 2, the differences are not significant. The egg-production values for the medium-protein group $(16 \%)$ are significantly higher than those for the high/low group and significantly higher for the percentage of egg production of the low/high group.

\section{EXPERIMENT 4}

The A lots were hatched on April 25, 1941, to repeat Experiment 2. Results are given in Table 5. These pullets matured satisfactorily. The mortality, compared with previous years, is not excessive but the production values are much lower than those obtained in the first year of Experiment 2. The production values, however, follow the same general trend as in the previous experiment.

The 1941-42 B lots included in this experiment were hatched on April 14, 1941, to repeat the range-reared lots of 1938-39. A mediumprotein $(16 \%)$ group is included in Table 5 for comparison. This group included pullets from both rearing groups.

The average yearly body and egg weights both differ significantly, the averages for the medium- and high-protein groups being larger than the low-protein group in both respects.

Compared with the previous range-reared B lots, the direction of the total mortality is reversed. In this trial the low/low group had the lowest mortality; the loss from cannibalism was not greater than that experienced in other low-protein groups, with the exception of the 1938-39 B group.

The egg-production values for the high/high group are significantly higher than those for the low/low group. As in the previous experiment (1940-41) with the medium level of protein, the eggproduction values exceeded those of the high-protein group, but in this trial the difference is not significant. 


\section{EXPERIMENT 5}

The A lots in Experiment 4 were less productive than those used previously. I' was decided to repeat this series a third time for further information on the effect of reversing the protein levels for the laying period as compared with those maintained on the same protein levels.

The pullets for the previous experiments had been hatched from the A lot eggs each year, starting with those in the 1936-37 trial. No selection for egg production was made. The first 2 years,

TABLE 5-Summary of Results for Experiment 4

\begin{tabular}{|c|c|c|c|c|c|c|c|}
\hline LOTS & \multicolumn{4}{|c|}{ A } & \multicolumn{3}{|c|}{ B } \\
\hline YEARS & \multicolumn{4}{|c|}{$\begin{array}{l}\text { 1941-42 } \\
\text { FIRST YEAR }\end{array}$} & \multicolumn{3}{|c|}{$\begin{array}{l}1941-42 \\
\text { FIRST YEAR }\end{array}$} \\
\hline Rearing ration-protein level... & 13.5 & 13.5 & 18.5 & 18.5 & $13.5^{*}$ & $18.5^{*}$ & $\begin{array}{l}13.5^{*} \\
\text { and } \\
18.5\end{array}$ \\
\hline Laying ration-protein level... & 13.5 & 18.5 & 13.5 & 18.5 & 13.5 & 18.5 & 16.0 \\
\hline Number of birds started... & 43 & 43 & 53 & 54 & 50 & 50 & 42 \\
\hline \multicolumn{8}{|l|}{ Average body weight (lb.) } \\
\hline At start............... & 3.15 & 3.21 & 3.20 & 3.28 & 3.09 & 3.16 & 3.11 \\
\hline Year................... & 3.32 & 351 & 3.54 & 3.55 & 3.52 & 3.72 & 3.67 \\
\hline L. S. D. for year $5 \%$ point... & \multicolumn{4}{|c|}{0.17} & \multicolumn{3}{|c|}{0.15} \\
\hline Average egg weight (gm.) & & & & & & & \\
\hline 1st period............ & 48.4 & 50.5 & 50.1 & 51.9 & 49.8 & 50.7 & 51.4 \\
\hline Year................... & 57.0 & 57.7 & 58.7 & 59.4 & 58.1 & 59.3 & 59.1 \\
\hline L. S. D. for year $5 \%$ point.. & \multicolumn{4}{|c|}{$0.14^{* *}$} & \multicolumn{3}{|c|}{$0.53^{* *}$} \\
\hline \multicolumn{8}{|l|}{ Mortality (percent) } \\
\hline Totalf........... & 30.2 & 20.9 & 20.7 & 16.7 & 20.0 & 34.0 & 33.3 \\
\hline Leukosis complex. ........... & 11.6 & 4.6 & 5.7 & 7.4 & 8.0 & 6.0 & 19.0 \\
\hline Reproductive disturbances... & 4.6 & 4.6 & 0.0 & 1.8 & 6.0 & 8.0 & 7.1 \\
\hline Miscellaneous............... & 13.9 & 11.6 & 15.1 & 7.4 & 10.0 & 20.0 & 9.5 \\
\hline Egg production (percent)........ & 36.4 & 49.1 & 41.1 & 49.6 & 51.1 & 56.8 & 58.2 \\
\hline L. S. D. $5 \%$ point. . & \multicolumn{4}{|c|}{$4.00^{* *}$} & \multicolumn{3}{|c|}{$4.48^{* *}$} \\
\hline $\begin{array}{l}\text { Production of survivors (eggs).. } \\
\text { L. S. D. } 5 \% \text { point.......... }\end{array}$ & 116.3 & 160.3 & 136.4 & 163.9 & 174.2 & 193.1 & 196.6 \\
\hline L. S. D. $5 \%$ point... & \multicolumn{4}{|c|}{$24.81^{* *}$} & \multicolumn{3}{|c|}{18.90} \\
\hline Av. lb. feed per doz. eggs.. & $\cdots$ & & & $\cdots$ & 5.6 & 5.1 & $\ldots$ \\
\hline $\begin{array}{r}\text { Av. lb. feed per bird per day }(13.5 \%) \ldots \\
(18.5 \%) \ldots\end{array}$ & \multicolumn{4}{|c|}{.231} & .242 & .241 & .241 \\
\hline
\end{tabular}

* Reared on grass range after 8 weeks of age.

+ Discrepancies caused by duplications (Table 9 ).

**Greatest difference exceeds 1-percent level of significance.

cockerels out of two or more dams in the Station breeding flock were used, but starting in 1939 cockerels from two dams only were 
used in the two pens of the A lots. These cockerels were changed every 2 days, but apparently an unfortunate choice of males was made in 1 or more years, since the quality of the pullets seemed to get worse as the experiment progressed. It was decided to obtain pullets for Experiment 5 directly from the Station breeding flock, which was being bred for low mortality and high egg production. The chicks were hatched on April 14, 1942. The results for these pullets are summarized in Table 6.

The average yearly body weight of the low/high group is significantly higher than that of any one of the three other groups which are comparable in this respect. In average yearly egg weight all groups are similar.

The total mortality does not differ significantly between lots. The trend, however, is the same as that which occurred in Experiment 2, 1938-39. The low/high protein group had the lowest total mortality in both experiments.

TABLE 6-Summary of Results for Experiment 5

\begin{tabular}{|c|c|c|c|c|}
\hline LOTS & \multicolumn{4}{|c|}{, . } \\
\hline YEARS & \multicolumn{4}{|c|}{ 1942-43 FIRST YEAR } \\
\hline 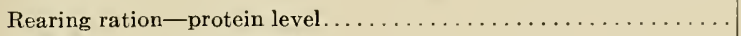 & 13.5 & 13.5 & 18.5 & 18.5 \\
\hline Laying ration-protein level. . . . . . . . . . . . . & 13.5 & 18.5 & 13.5 & 18.5 \\
\hline Number of birds started . . . . . . . . . . . . . & 53 & 53 & 56 & 56 \\
\hline Average body weight (lb.) & & & & \\
\hline 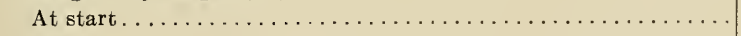 & 3.06 & 3.11 & 3.14 & 3.10 \\
\hline 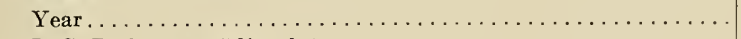 & 3.63 & 3.77 & 3.61 & 3.65 \\
\hline L. S. D. for year $5 \%$ point. $\ldots \ldots \ldots \ldots \ldots \ldots \ldots \ldots \ldots$ & & $0.10^{*}$ & & \\
\hline \multicolumn{5}{|l|}{ Average egg weight (gm.) } \\
\hline 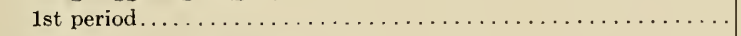 & 46.2 & 45.9 & 46.1 & 45.5 \\
\hline 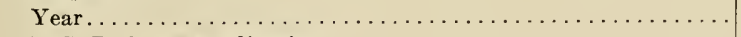 & 54.7 & 55.0 & 55.0 & 54.9 \\
\hline 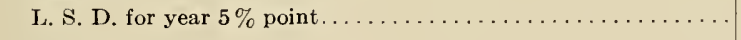 & & 0.41 & & \\
\hline \multicolumn{5}{|l|}{ Mortality (percent) } \\
\hline Total,$\ldots \ldots \ldots \ldots$ & 26.4 & 15.1 & 25.0 & 21.4 \\
\hline Leukosis complex. . . . . . . . . . . . . . . . . . . . . & 13.2 & 3.8 & 8.9 & 8.9 \\
\hline Reproductive disturbances $\ldots \ldots \ldots \ldots \ldots \ldots \ldots \ldots \ldots \ldots$ & 5.7 & 1.9 & 5.3 & 5.3 \\
\hline Miscellaneous . . . . . . . . . . . . . . . . . . . . . . . . & 9.4 & 9.4 & 14.3 & 7.1 \\
\hline \multirow{2}{*}{ 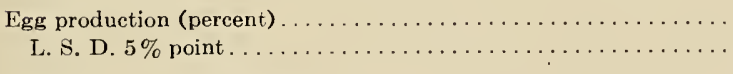 } & 54.5 & 66.1 & 53.7 & 61.8 \\
\hline & \multicolumn{4}{|c|}{$3.39^{* *}$} \\
\hline Production of survivors $(\mathrm{eggs}) \ldots \ldots \ldots \ldots \ldots \ldots \ldots \ldots \ldots \ldots$ & 188.7 & 221.1 & 182.7 & 205.8 \\
\hline 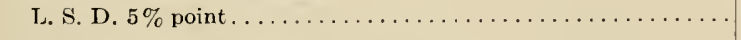 & \multicolumn{4}{|c|}{$17.42^{* *}$} \\
\hline 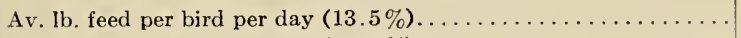 & \multicolumn{4}{|c|}{.264} \\
\hline$\ldots \ldots \ldots \ldots \ldots$ & \multicolumn{4}{|c|}{.262} \\
\hline
\end{tabular}

**Greatest difference exceeds 1-percent level of significance

The trend of egg-production values is similar to that for Experiment 2. In this experiment the percentage value of the low/ 
high group is significantly higher than those of the other three groups, while the low/low value is very close to the high/low value. In Experiment 2 the low/low group was lowest, and the three other groups did not differ from each other significantly. The production values of the survivors differ from those of the former experiment in the same manner as the percentage values.

\section{DiscUSSION}

Egg Production-In all lots within the year, the values for percentage of egg production of the first laying year for the low/low protein level are lower than those for the high/high protein level. In only one experiment $(1939-40 \mathrm{~B})$ is the difference not significant. Pairing the seven low-and high-ration-groups percentages for those shown in Table 7 , to eliminate years, the $t$ value, 6.33 , of the mean difference is highly significant.

In all ration groups which differ significantly within years, the trend for the percentage values and for the production of survivors is in the same direction. In only two cases do the percentage values differ, while the production of survivors does not differ significantly (1936-37A, 1941-42B). These lots were reared on range, and this environment, together with mortality, may have conditioned the results. The second-year production values for the 1937-38A lot are r eversed but the differences are small and not significant. In the lots that were maintained for 3 years the trend is consistent throughout all years. Those that were low or high the first year maintained about the same relative position in later years.

The yearly values for percentage of production in the first laying year for the four main ration groups are summarized in Table 7. The averages for all lots within rations show that the low/low and the high/low values are comparable; both ration groups vary from 7 to 8 percent lower than the other two groups. Growing the pullets on the low-protein and then changing to the high-protein ration produced significantly more eggs than did growing the pullets on the high and then changing to the low protein level. The results suggest that the requirement of protein for egg production is higher than that for growth after 4 weeks of age, at least, under the conditions of this experiment. In actual practice, however, a ration containing as little as 13.5 percent protein is seldom fed, especially during the first two months.

The experiment provides some information suggesting that it might not be necessary to go as high as 18.5 percent and that 16 percent might be sufficient for satisfactory egg production when the pullets are reared on a low protein level. Table 8 describes the B lots 1939-40, 1940-41, and 1941-42, in which birds from the two rearing groups were combined to make a third group. The results for the laying period are shown according to rearing groups. Because 


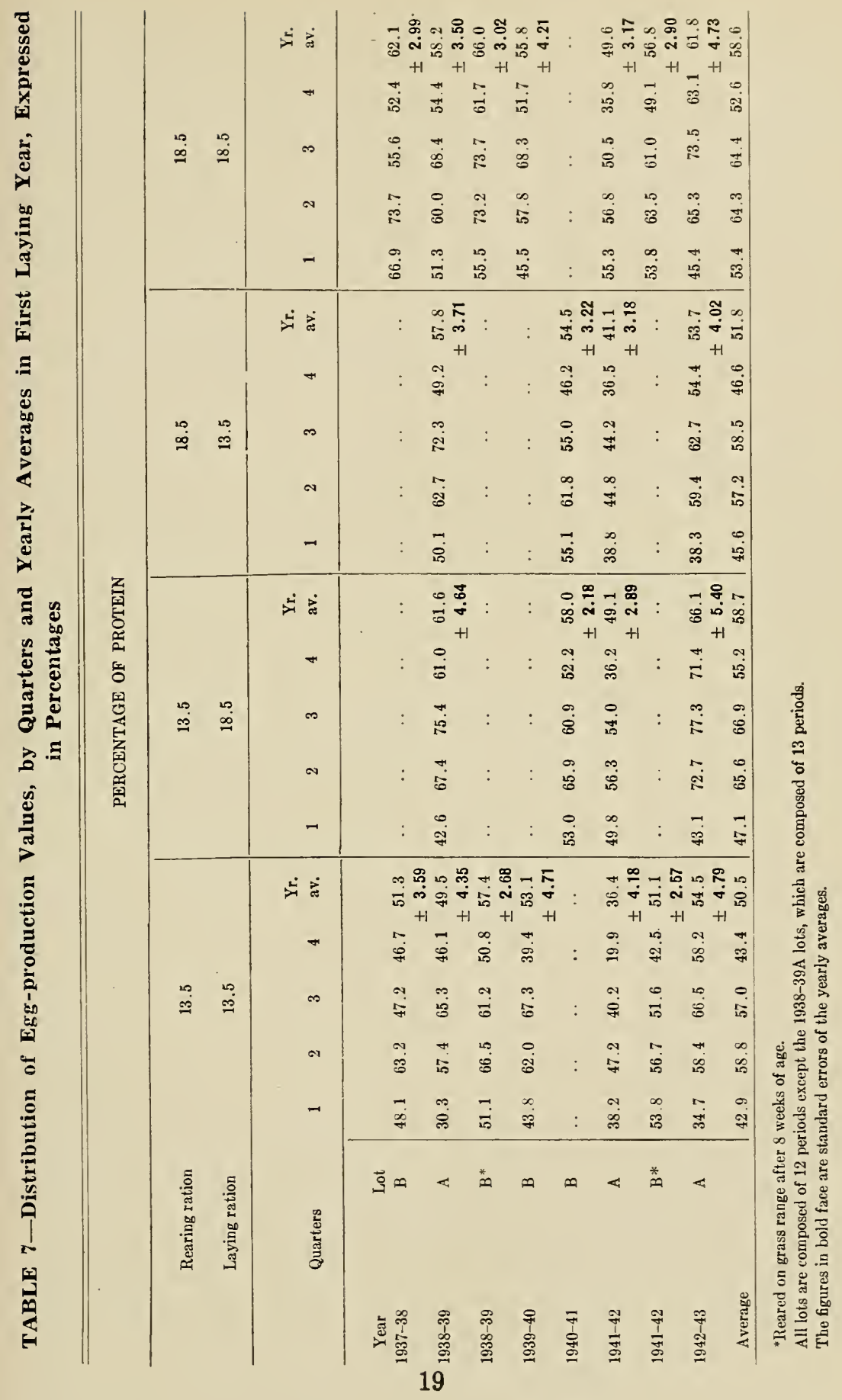


of the small numbers and the high mortality, in some lots, no definite conclusions can be drawn. But from the production standpoint, when the 16-percent-protein laying ration was used, it made little difference whether the rearing level had contained 13.5 or 18.5 percent of protein. Certainly is was not necessary to feed as high as 23.5 percent protein in the laying period when either of these rearing levels was used.

At the outset it had been planned to obtain accurate information on the effect of protein level in the rearing period on the average number of days required to reach sexual maturity. In some lots this was not possible because of limitations in housing and other facilities. The birds frequently had started to lay before they could be moved to the laying pens and trapnested.

In Table 7, the values for percentage of egg production for the four ration groups are presented by quarters. The averages for all lots show that the low/low protein groups are lower throughout all quarters than the high/high protein groups. Considering the two reversed ration groups, the low/high started off slower in two of the four groups, but the quarterly averages are all higher than those for the high/low protein groups.

Comparing the first-quarter egg production of the low/low and the high/high groups, it will be seen that the high/high exceeded

\section{TABLE 8-Division of Laying Groups According to Rearing Rations}

\begin{tabular}{|c|c|c|c|c|c|c|}
\hline Rearing Ration. & 13.5 & 18.5 & \multirow{2}{*}{\multicolumn{2}{|c|}{$\begin{array}{l}13.5 \\
16.0\end{array}$}} & \multirow{2}{*}{\multicolumn{2}{|c|}{$\begin{array}{l}18.5 \\
16.0\end{array}$}} \\
\hline Laying ration. ..... & 23.5 & 23.5 & & & & \\
\hline Year & $1939-$ & & $1940-41$ & $1941-42^{*}$ & $1940-41$ & $1941-42^{*}$ \\
\hline No. started. & 27 & 27 & 23 & 20 & 20 & 22 \\
\hline Mortality (percent). & 29.6 & 18.5 & 47.8 & 45.0 & 40.0 & 22.7 \\
\hline Egg production (percent). & 55.5 & 52.0 & 63.2 & 60.0 & 62.4 & 56.3 \\
\hline Average yearly body weight(lb.) & 3.4 & 3.4 & 3.5 & 3.6 & 3.7 & 3.6 \\
\hline
\end{tabular}

${ }^{*}$ Reared on grass range from 8 to 20 weeks of age.

the low/low in all but one lot, and here the production is equal. Two of the three lots with the least difference were reared on range. Thus it appears that rearing on range had a beneficial effect during the first period on the low-protein group. For the seven pairs of groups in the first quarter the $t$ value is 3.23 , which is significant at the 5-percent level. For the remaining quarters the differences in favor of the high/high protein level are highly significant, suggesting that the high protein in the laying ration had more influence on egg production in the later quarters than in the first quarter. The first periods of these two ration groups were highly variable, the widest difference being in the 1937-38B lots, which were started at day-old on the respective rations. 
There is no evidence that the high protein rations (18.5 or 23.5) overstimulated egg production and brought about any attendant ills such as neck molt.

Mortality-It is difficult to draw definite conclusions concerning the relation of the level of protein in the ration and mortality because little is known about the conditions causing death in chickens. Undoubtedly, many environmental and physiological factors may shorten life. In all these trials, conditions within lots in the same year were, except for protein level, nearly identical. Sisters were divided between the ration groups, and presumably all were subjected to the same environment and to the same diseases. There were no infectious diseases except an outbreak of fowl pox in 193940 , for which the pullets had been vaccinated. Slight attacks of coryza also occurred and these appeared to be no more severe on one protein level than on another.

That environment may have had some influence on mortality is suggested by the "percent died" column in Table 9. Two of the lots were reared on a bluegrass range. In the 1938-39 lot the mortality, due largely to cannibalism, is highest for the low/low group, while in the 1941-42 group the mortality, though not as high, is reversed. In the other five of the low/low and the high/high groups in this table the percentage of mortality for the former groups is higher in all cases. In some instances the difference is not very great, with the result that for the remaining five paired groups reared in confinement $t$ is 2.84 , which exceeds the 5-percent level of significance. This evidence suggests that even where management is held constant and feeding is variable, definite conclusions on mortality cannot be drawn without large numbers of birds.

While the differences are not highly significant, the tendency is for the low-protein groups to have a higher percentage of mortality, suggesting an inverse relationship between level of protein feeding and mortality. There is also evidence that mortality is inversely related to egg production because, as already shown in Table 7 , the low/low groups had a significantly lower egg production than did the high/high groups. It is logical that mortality and egg production should be inversely correlated since factors contributing to low egg production probably contribute also to high mortality. In the present experiment it has been shown that the low/low level of protein feeding was too low to support satisfactory egg production. It can be inferred also that this level was one of the factors contributing to a slightly higher rate of mortality. The mortality rate for the ration groups in Table 9 suggests that, when the low-protein ration was fed in both growing and laying periods, the effect was cumulative. When the protein level was shifted from low to high at sexual maturity, this effect apparently was overcome. Reversing the protein level in either direction at sexual maturity had less effect on mortality than it did on egg production. There is no evidence that levels of protein in the rations were as- 


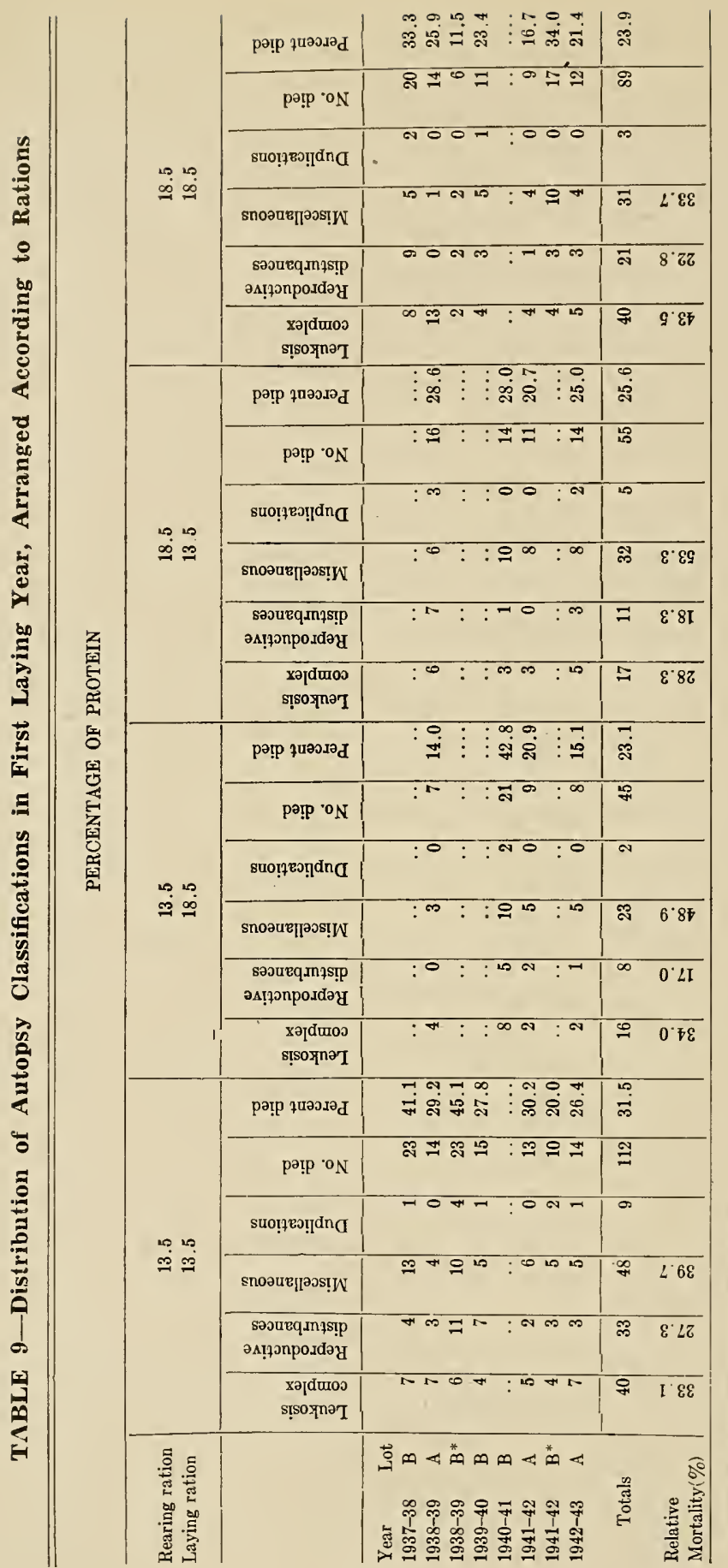




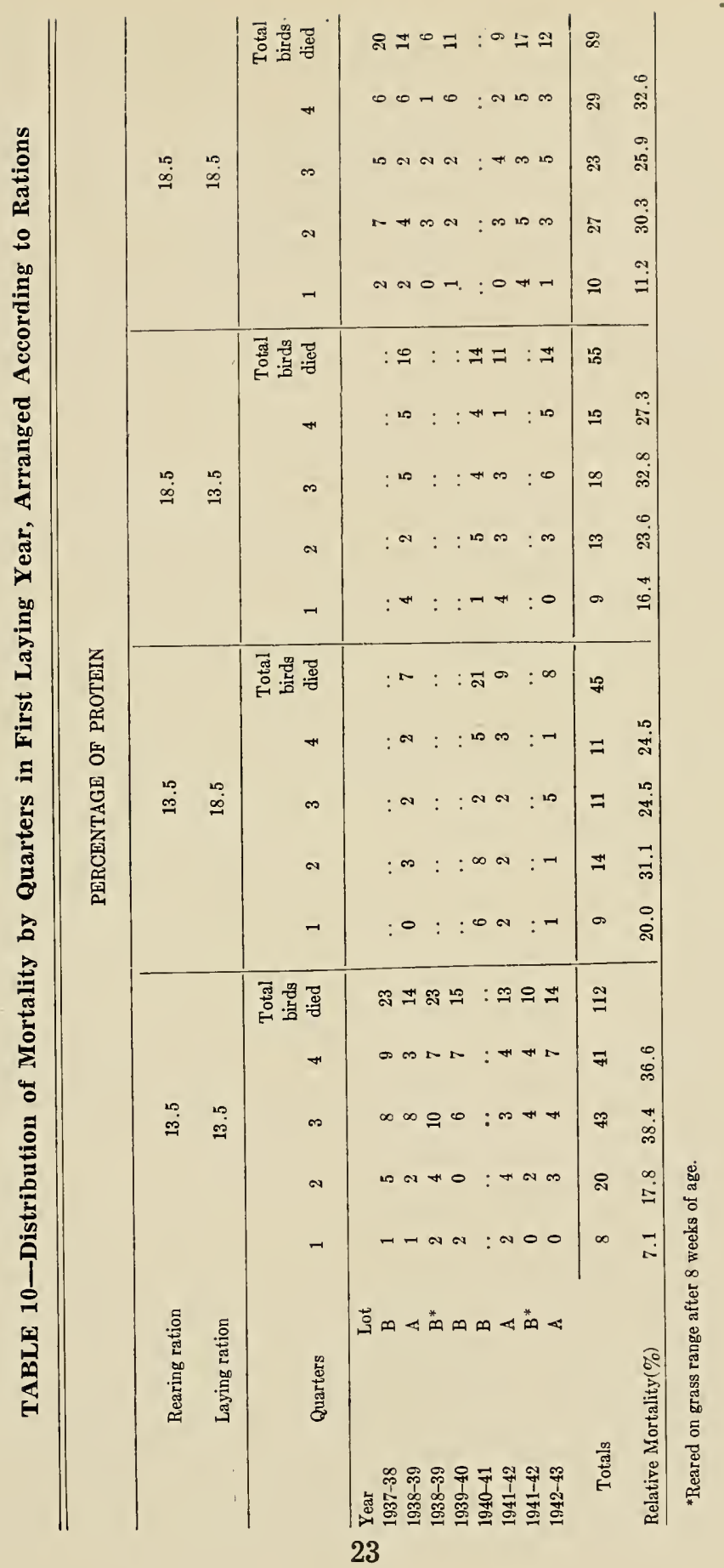


sociated with the occurrence of the various disease classifications in Table 9 , there being no significant trend among the ration-groups.

The distribution of mortality by quarters is shown in Table 10 . The only distinct trend in this table is that the mortality in the first quarter is lowest compared with that oceurring in the following quarters, a fact commonly observed under average conditions. There is no evidence in the following periods that the mortality was highest during the periods of high egg production.

The results obtained in Experiment 2, Table 3, are of interest from the mortality standpoint. In the first laying year the low/high protein group had a much lower mortality than did any of the three other groups. The total mortality, however, over the 3 -year period for the four comparable groups was equalized as shown previously. Thus, if the protein level had any influence it did not extend beyond the first year. Reversing the protein level at laying age produced a consistently lower percentage of mortality in the three comparable groups as compared with the mortality of the low/low groups. In Experiments 2 and 5 the mortality for the low/high group is appreciably lower than that of the other groups. As shown in Table 3 this influence, if caused by the proteir level, did not extend beyond the first year of Experiment 2. Over the 3-year period the mortality was equalized. - Thus, if the mortality was influenced the first year, environmental and other influences later overcame the effect of the protein. However, since layers are kept only for one laying year as a rule, it might be profitable to grow the pullets on a fairly low protein level and then raise them to a higher level at laying time. The evidence, both for mortality and egg production, suggests that perhaps laying hens require more protein than is commonly recommended. It will remain for future experiments to decide these points fully.

The highest protein level used $(23.5 \%)$ did not appear to have an adverse effect on viability, although only one trial was made using this level. The two trials using the 16 percent level of protein exhibited no effect on the mortality, although again the numbers are limited.

The total mortality during the growing period is shown in Table 11. Here it will be seen that in the first lots (1937-38B) which were started at day-old on the different levels of protein, the lowprotein lot had a much higher mortality than the other lot. This held true also in the laying period. The differences for the other lots that were grown to 4 weeks on the 18.5 percent level are not consistent, indicating that factors other than protein level influenced mortality. There appears to be no relationship of mortality in the growing period to that in the laying period.

Feather-picking was prevalent in all low-protein lots in both rearing and laying periods. Unlike the bare breasts observed by 


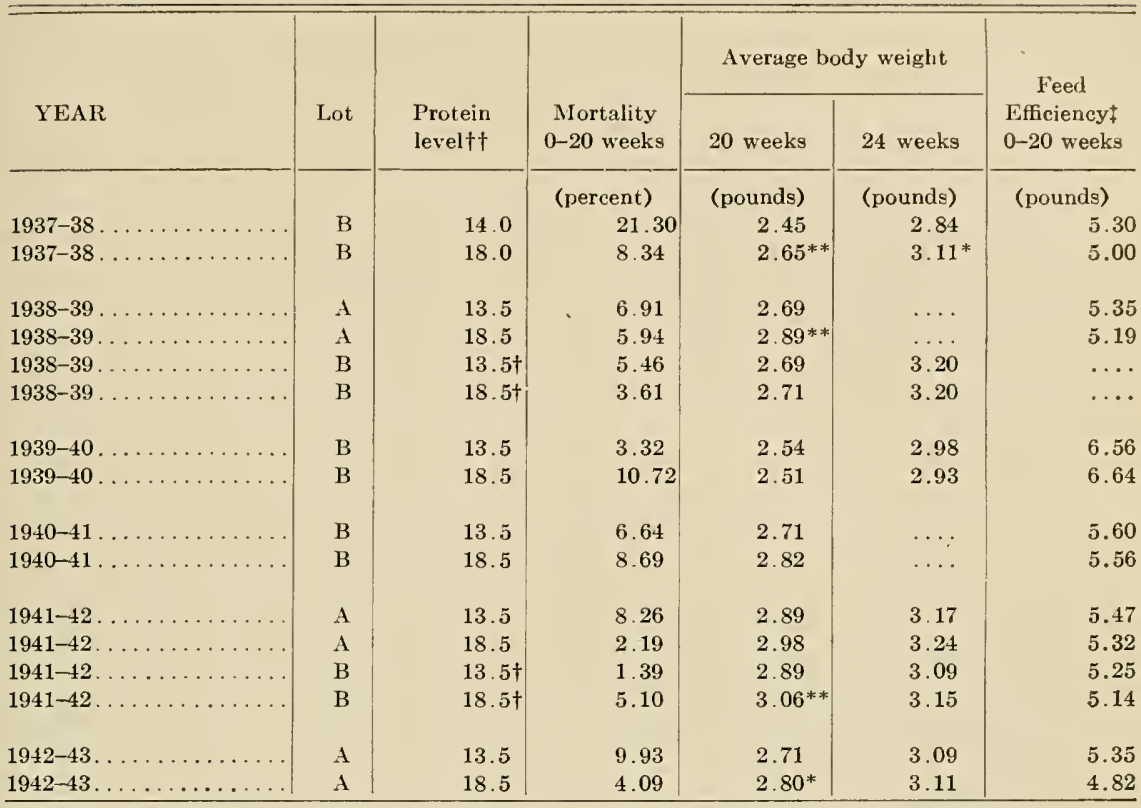

$+\dagger$ All lots were fed the 18.5 percent protein ration to 4 weeks of age except the 1937-38 lots.

$\dagger$ Reared on grass range after 8 weeks of age.

$\ddagger$ Pounds of feed consumed per pound of gain in body weight.

* Difference significant at 5-percent point.

**Difference significant at 1-percent point.

Tomhave (18), the abdominal area was picked bare in these experiments during the growing period and this picking extended to the back in the laying period. In a few trials cannibalism occurred in the confined lots during the rearing period, and an occasional outbreak occurred in the laying pens. After the serious outbreak in the 1938-39B low-protein lot, which resulted in high mortality, the point of the upper beak was cut off and this usually prevented any further serious outbreaks. Unpublished data from this Station support the contention that the feather-picking and cannibalism were due largely to lack of protein in the ration rather than to a high percentage of corn in the ration.

There is little information available on the effect of feeding very high protein levels to layers. Miller and Bearse (14) found that a ration containing 30 -percent protein concentrate did not produce a high percentage of organic trouble. In the present experiments no evidence was obtained suggesting that high protein levels in either growing or laying periods tended to increase mortality.

Confirming the results obtained by Tomhave (18), the use of range during the 8 - to 20 -week period did not result in consistently reduced mortality in the laying period. 
Body Weight-The results of the majority of experiments reported in the literature agree that the early growth of chicks increases with an increase in protein level up to about 20 percent and that this protein level can be decreased as the birds mature. The decrease can be made gradually after the birds are 6 to 8 weeks old. In this experiment the decrease from 18.5 to 13.5 percent was made at four weeks of age. This is both earlier and a greater reduction than is recommended. Judging from the results of other investigators, had the protein been maintained on the high level for a longer period, it is likely that the differences in body weight would not have occurred as shown in Table 11.

The average body weights for the two ration groups during the growth period are shown in Figure 1. The 1937-38B lots are not included because they were fed differently in the first 4 weeks. The average weights for those fed the low protein are below those for the high-protein-fed lots throughout the growth period. The averages for all lots at 20 and 24 weeks are shown in Table 11. At 20 weeks of age, only 4 of the 8 pairs of lots differ significantly. Of those that were in comparable groups at 24 weeks of age, and not culled, only 1 of the 6 pairs differed significantly. For the most part, the trend is for the lots on the lower protein to be lower in weight than those on the higher protein. This lower body weight continued throughout the laying period for all the low/low groups, as shown in Figure 2.

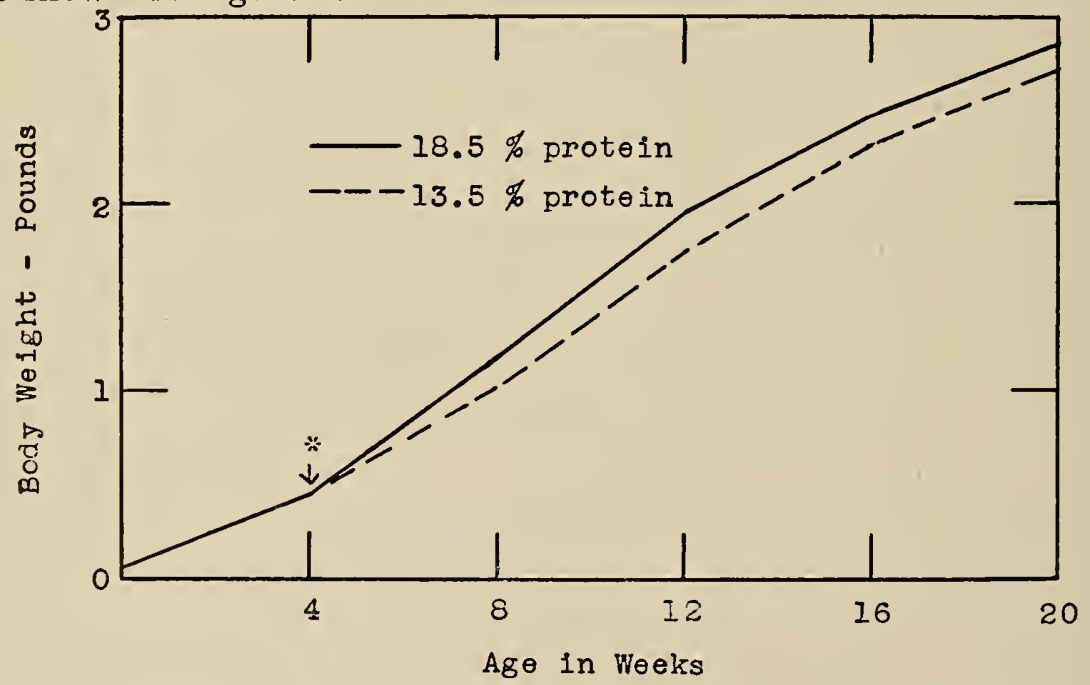

*All lots fed $18.5 \%$ protein to 4 weeks Figure I

Average Body Weight of Pullets According to Ration Groups

Summarizing the average yearly body weights for the same seven ration groups as given in Table 7 , the $t$ value for the differ- 


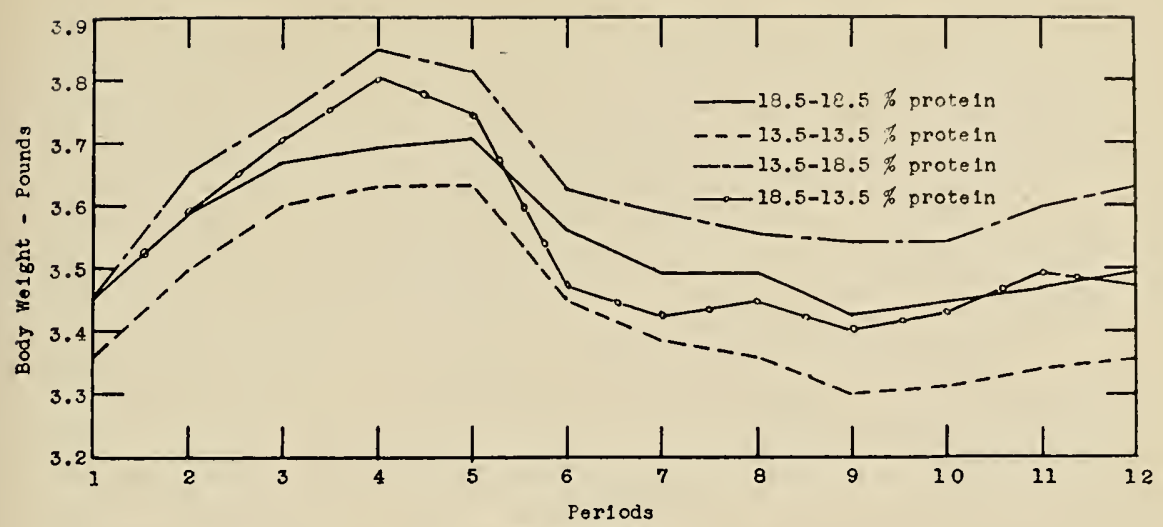

Figure 2

\section{Average Body Weights During First Laying Year According to Ration Groups}

ences of the paired groups, low/low and high/high, was 2.92, which is significant at the 5-percent point. When the rations were reversed, the average body weight for three of the low/high groups was above that for the high/low groups. This is definite evidence that protein is essential for maintaining body weight during the laying period.

The theory is frequently advanced that pullets should be grown slowly. At first glance these results tend to support this theory, for when the pullets were reared on a low protein and then shifted to a higher protein, better results were obtained. On the other hand, when all lots are considered, the shifted groups did no better than those kept on the high/high protein ration throughout. Furthermore, only 2 of the lots that were reversed differed significantly in body weight at 20 weeks of age. Therefore the beneficial results from shifting rations can hardly be explained on the basis of body weight or of the rate of growth to 20 weeks of age.

The results do suggest that pullets can be grown efficiently on a 13.5-percent protein ration and that the protein required to maintain body weight during the laying period is more than 13.5 percent.

A study of the 1938-39 lots showed that percentage of growth rate and egg production were not related statistically. Egg production appears to be less dependent on rate of growth before sexual maturity, or on body weight at sexual maturity, than cn the ability of the ration to maintain body weight during the laying period.

Egg Weight-There is some disagreement in the literature regarding the effect of protein level in the ration on egg weight. Some investigators have reported definite relationship, while others have found little or no relationship between protein level and egg weight. Referring to the egg-weight data for the groups listed 


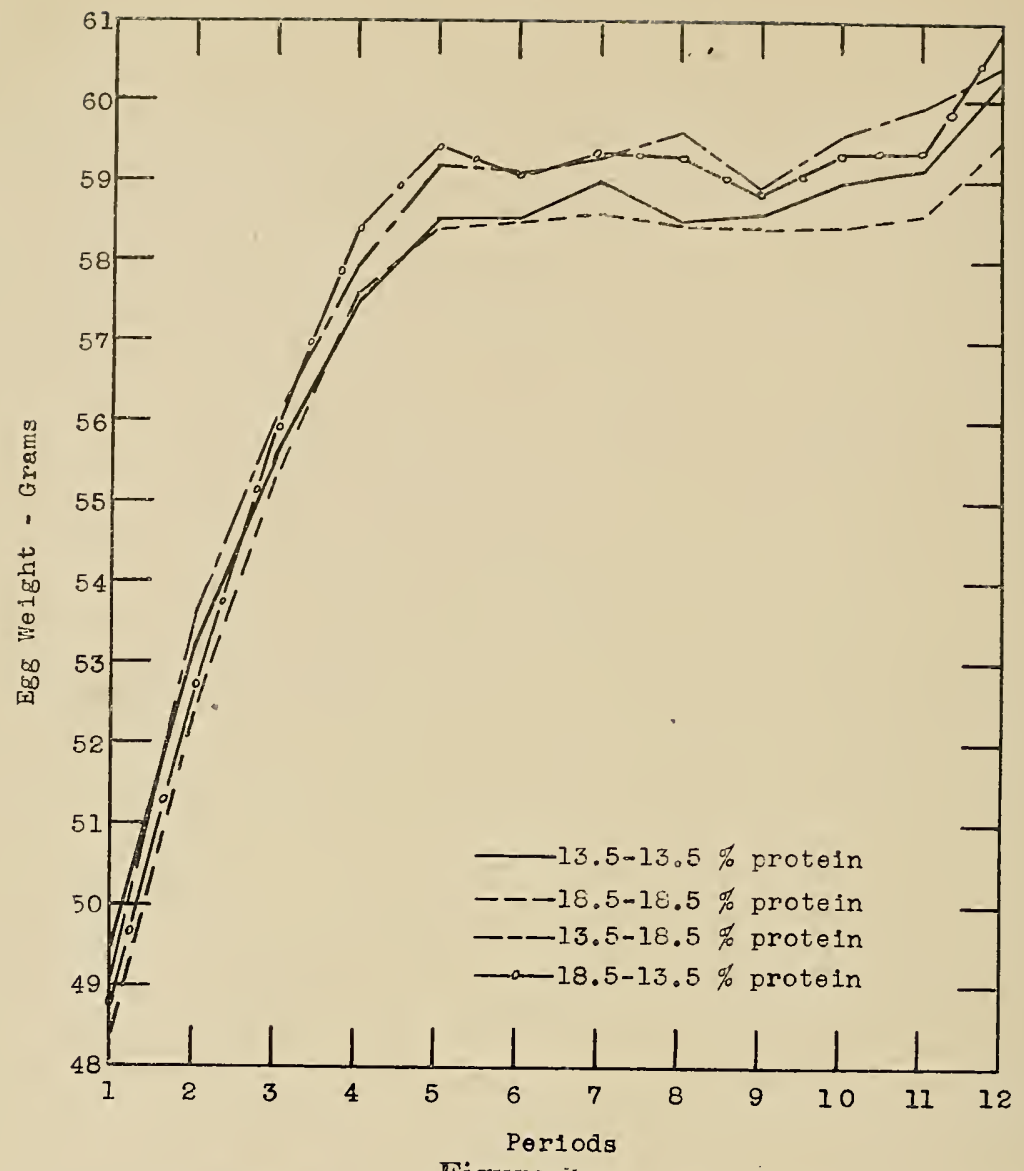

Figure 3

\section{Average Egg Weights During First Laying Year According to Ration Groups}

in Table 7, neither the average weight for the first period nor the yearly averages of the low/low protein groups differ significantly from those of the high/high groups. In the reversed groups the differences are not consistent; the effect is about balanced for the eight ration groups. Even though the average yearly body weight for the high/high groups was significantly higher than that for the lcw/low protein groups, the low protein level did not show such a marked effect on the average yearly egg weight. It will be seen in Figure 3, however, that although the curves are closely grouped and parailel each other throughout the laying period, the curve for the low/low group is below that of any other group. A similar effect was noted for the body weights (Fig. 2).

Whi.e the protein levels did not have a significant influence on 


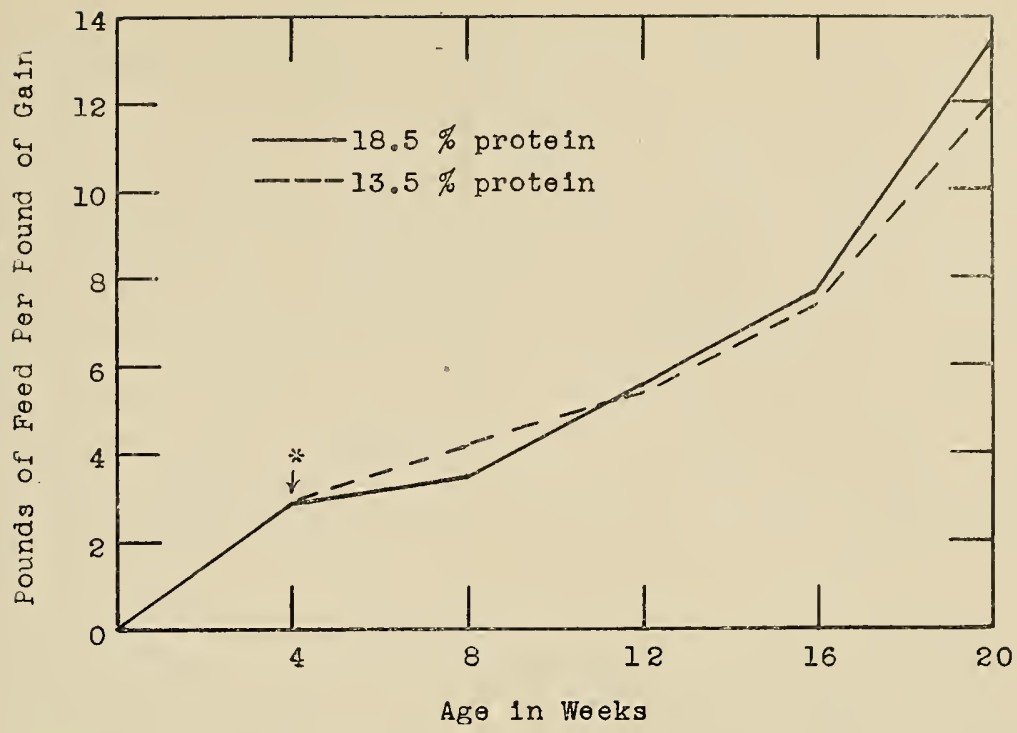

$\because$ All lots fed $18.5 \%$ protein to 4 weeks

Figure 4

Average Pounds of Feed Consumed Per Pornd Gat Gain in Body Weight of Pullets According to Ration Groups

the average yearly egg weight under the conditions of this e-roriment, there is a distinct trend for the egg weight of the low/low protein groups to be lower than that for any other group. This did not ccour in all lots even during the first laying period; hence it cannot be inferred that low protein levels will always result in cmaller eggs. However, in some lots the influence was so marked that the chicks from these low-protein-fed lots were signifiantly smaller when hatched than those from the high-protein lots.

Feed Efficiency-The average pounds of feed consumed per pound of gain in body weight from 0 to 20 weeks of age is shown for the pullets in Figure 4. The 1937-38 lots were not used in these averaçes. All lots included were fed the 18.5 percent protein ration to 4 weeks of age. The figure shows that the high-protein ration was util zed more efficiently from 4 to 8 weeks. From 9 to 12 weeks the rations were comparable, but after this period the low-protein vation was utilized more efficiently. The difference of 0.51 rounds ut 8 weeks only is significant.

The average feed efficiency of all but 2 lots for the entire growth period is given in Table 11. The averages for those used in Figure 4 are 5.59 and 5.44 for the low- and high-protein-fed lots, respectively. The difference is not significant. Between 13 and 20 vveks of age, the percentage rate of growth was greater for the low pro- 
tein lots, which explains the lower feed-eficiency value for this period. The increased growth in this period was almost great enough to overcome the advantage obtained by the high-protein lots from 5 to 12 weeks of age.

The average pounds of feed consumed to produce a dozen eggs is shown for the lots containing a single-rearing group in Tables 2,4 , and 5. In all cases the feed consumed per dozen eggs laid is the highest for those fed the 13.5-percent protein ration. Even though these birds laid fewer eggs than those fed the 18.5 percent protein ration, they consumed, on the average, more feed as shown by the average pounds of feed consumed per bird per day in Tables 2 to 6 , inclusive. The average difference in feed consumed per bird per day for the 10 pairs of lots is 0.004 pounds lower for the high-protein ration, which, with a $t$ value of 2.8 , exceeds the 5 percent level of significance.

\section{General Discussion}

The literature review suggests that rations which permit normal rate of growth will permit normal rate of egg production. The results reported herein clearly show that rations which are low enough in protein to retard growth will reduce egg production and have a detrimental influence on viability when fed at the same level in the laying period. The chief point of interest is that effects of the low-protein growing rations were overcome to a large extent by shifting to a higher protein level at 20-24 weeks of age.

Considering growth, mortality, and feed efficiency, White Leghorn pullets can be grown in confinement fairly satisfactorily when the protein level is reduced to 13.5 percent at 4 weeks of age. The results show, however, that a ration containing 18.5 percent protein is utilized more efficiently to 8 weeks of age. When the lowprotein ration was fed from 4 weeks of age, the pullets were slightly lower in body weight at sexual maturity. The low protein level did not have a marked effect on egg weight, but it slowed up egg production in the first three 28-day periods even when the protein level was increased to 18.5 percent at laying age. These observations are important if the egg producer wants eggs early in the fall, when prices are high. If pullets are to be grown slowly, they must be started earlier.

No evidence was found that rearing pullets on range decreases mortality in the laying pen as compared with those reared in confinement. In fact the results suggest that range-reared pullets require more careful management when they are moved to the laying quarters to prevent outbreaks of cannibalism, compared with pullets grown in confinement.

No evidence was found that growing the pullets on a highprotein ration increased mortality in the laying period. Likewise, 
no evidence was found that a high-protein laying ration increases mortality in the laying period. This evidence appears to rule out high protein levels as a factor in mortality. Neither the 18.5 nor the 23.5 percent levels of protein appeared to overstimulate egg production, and in all lots less cannibalism and feather-picking occurred on the high level than on the lower levels of protein. While it may not be necessary to use as high as 18.5 percent of protein in the laying ration, this percentage did not prove to be harmful in these experiments. On the other hand, these results prove that a 13.5 percent level in an all-mash laying ration is inadequate whether or not this level is used in the rearing period.

Under practical conditions, all-mash rations are seldom used. It is not believed, however, that the all-mash method of feeding affected the results in these experiments appreciably. This method made certain that all birds received the necessary nutrients other than protein. In these experiments, protein undoubtedly was the limiting factor in the case of the low-protein ration. Evidence had been obtained on this point, before this work was started, from unpublished experiments with free-choice feeding. When the birds consumed unlimited quantities of grain in the laying period, results similar to those with the low-protein ration were obtained, indicating that the protein intake was too low. Insufficient evidence was obtained to show just how high the protein level should be in the present experiments, but from two trials the results suggest that 16 percent in the laying ration will give satisfactory results. This level gave satisfactory results even when the pullets were reared on the 13.5 percent level. It should be pointed out too that the 18.5 percent level was more economical than the 13.5 level when the feed consumed per dozen eggs was considered. The additional eggs produced by most lots fed the high protein level more than paid for the additional cost of the ration. From this standpoint there was little difference between the 16 and the 18.5 percent levels from the few available comparisons. Egg producers then would be justified in restricting the grain consumption throughout the laying period, so that the protein intake would be maintained at around 16 percent.

\section{Summary AND Conclusions}

A series of experiments extending over a 7-year period was conducted with 1485 White Leghorn pullets maintained under nearly identical conditions within the year in both rearing and laying periods. The pullets were fed all-mash rations comparable in all known respects except level of protein. The following results were obtained from this study:

1. Feeding a 13.5 percent protein ration from 4 to 20 weeks of age resulted in a slightly lower body weight than that obtained from an 18.5 percent protein ration. 
2. The 18.5 percent protein ration was utilized more efficiently from 5 to 8 weeks of age. From 9 to 12 weeks the rations were comparable, but from 13 to 20 weeks the 13.5 percent protein ration was utilized more efficiently.

3. Lowering the protein level from 18.5 percent to 13.5 percent at 4 weeks of age did not increase the mortality over that resulting when an 18.5 percent level was fed throughout the growth period.

4. A protein level of 13.5 percent after 4 weeks of age throughout both the rearing period and the first laying year resulted in higher mortality and in significantly lower percentage of egg procuction the first laying year as compared with the results obtained when the 18.5 percent protein level was fed in both periods.

5. Increasing the protein level from 13.5 percent to 18.5 percent at sexual maturity resulted in a higher egg production than when the protein level was shifted from 18.5 percent to 13.5 percent at the same age. The average percentage of egg production of the latter group was almost as low as that for the pullets fed the 13.5percent protein level throughout both rearing and laying periods.

6. Reversing the protein level in either direction at sexual maturity had, on the average, little effect on the percentage of mortality.

7. Evidence from two experiments suggests that when pullets are grown on a 13.5-percent protein ration, a 16 -percent ration will give as satisfactory results in the laying period as an 18.5-percent ration.

8. Maintaining the layers for three years on the low and the high levels of protein had little influence on mortality when the three years are considered as a single period. In all years the different groups maintained about the same relative position in egg production. The egg production on the average was not affected by the rearing ration.

9. A protein level of 23.5 percent in the laying period did not increase mortality as compared with the 18.5-percent level and, like the latter level, did not overstimulate egg production.

10. Cannibalism was more prevalent in the low-protein than in the high-protein lots during both growing and laying periods.

11. The average yearly body weight was significantly higher for the lots on the high/high protein levels as compared with those on the low/low protein levels. In the reversed lots the 18.5-percent level of protein generally maintained a higher average body weight than did the 13.5-percent level.

12. The 18.5-percent protein ration produced on the average a ciozen eggs on fewer pounds of total feed than did the 13.5-percent protein ration. The average pounds of feed consumed per bird per 
day was significantly lower for birds on the high protein level than for those on the low protein level.

13. Protein level did not have a significant influence on the average yearly egg weight, although the average egg weight for the low low protein lots was generally below that for the higher-protein-fed lots.

14. Growing the pullets on grass range after eight weeks of age was not more beneficial in regard to egg production or to viability than growing the pullets in confinement, regardless of the level of protein used.

Under the conditions of this experiment the level of rrotein seemed to be more important in the laying than in the rearing period. Regardless of the level of protein fed in the rearing period, after the brooding stage, it is concluded that, for consistently high egg production and for low mortality, the level of protein in the laying ration should be higher than that generally recommended. Maintaining at least a 16 percent level of protein would appear to be a sound economic practice.

\section{ACKNOWLEDGMENT}

The authors are indebted to Dr. H. L. Lucas, Institute of Statistics, North Carolina Agricultural Experiment Station, for advice concerning certain statistical analyses and to Mrs. Gertrude L. Shaffer for assembling and analyzing the data.

\section{Literature Cited}

(1) Atwood, Horace. 1923. Influence of rations fed to growing chickens on the characteristics of the adult females. W. Va. Agr. Expt. Sta. Bul. 179.

(2) Bronkḥorst, J. J. 1938. The influence of the protein level of diet on the growth, egg production, egg weight and mortality of single-comb White Leghorn pullets. Onderstepoort Vet. Sci. 10: 469-479.

(3) Byerley, T. C., H. W. Titus, and N. R. Ellis. 1933. Production and hatchability of eggs as affected by different kinds and quantities of proteins in the diet of the laying hen. Jour. Agr. Res. 46:1-22.

(4) Carver, J. S., J. L. St. John, T. E. Aspinall, and I. H. Flor. 1932. Protein requirements of chickens. Poultry Sci. 11: 45-57.

(5) Carver, J. S., J. L. St. John, Wayne IM. Miller, and Gordon E. Bearse. 1935. The comparative efficiency of various proteins for growing chickens. Wash. Agr. Expt. Sta. Bul. 321.

(6) Carver, J. S., J. Heiman, J. W. Cook, and J. L. St. John. 1939. The frotein requirements of White Leghoin pullets. Wash. Agr. Expt. Sta. Bul. 383. 
(7) Dearstyne, R. S., C. O. Bollinger, C. K. Jones, and H. P. Brigman. 1936. The influence of certain protein levels on the growth of pullets. $N$. C. Agr. Expt. Sta. Bul. 304.

(8) Gutteridge, H. S., J. B. O'Neil, and Jean M. Pratt. 1943. Level and source of protein in poultry production: I. As related to economical production of growth in pullets. Scientific Agri. 24: 164-175.

(9) Gutteridge, H. S., Jean M. Pratt, and J. B. O'Neil. 1944. Level and source of protein in poultry production: II. As related to economical production of eggs. Scientific Agri. 24: 240-250.

(10) Hill, D. C. 1944. Protein in poultry nutrition. Scientific Agri. 24: 551-590.

(11) Heiman, V., J. S. Carver, and J. L. St. John. 1936. The protein requirements of laying hens. Wash. Agr. Expt. Sta. Bul. 336.

(12) Heuser, G. F., and L. C. Norris. 1933. The influence of the protein level on the growth of chickens and its relation to subsequent behavior. Proc. V. World's Poultry Congress (Rome) II: 551-558.

(13) Heuser, G. F. 1936. The protein requirements of laying hens. Proc. VI. World's Poultry Congress (Leipzig) I: 276-279.

(14) Miller, M. W., and G. E. Bearse. 1930. Feeding excess protein to laying hens. Ann. Rpt. Western Wash. Expt. Sta. Bul. 18W, s.: 27-29. (Quoted from D. C. Hill. See reference 10.)

(15) Morris, L., R. B. Thompson, and V. G. Heller. 1932. The effect of varying the amounts of protein in the poultry ration on chick growth and subsequent egg production. Poultry Sci. 11: 364.

(16) Platt, C. S., and H. W. Stover, Jr. 1945. Sexual maturity, adult mortality, and egg production of White Leghorn pullets in relationship to their diet during the growing period. New Jersey Agr. Expt. Sta. Bul. 716.

(17) St. John, J. L., J. S. Carver, O. Johnson, and D. Brazie. 1933. Optimum protein levels for chickens. Proc. V. World's Poultry Congress (Rome) II: $567-573$.

(18) Tomhave, A. E. 1939. Protein levels of rations for White Leghorn pullets. Del. Agr. Expt. Sta. Bul. 219.

(19) Winter, A. R., E. L. Dakan, and A. Bayes. 1932. Protein levels for finishing pullets. Poultry Sci. 11: 30-33. 





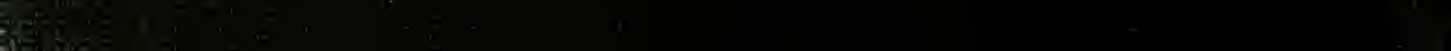

